\title{
Interactive Effects of Grafting and Manganese Supply on Growth, Yield, and Nutrient Uptake by Tomato
}

\author{
Dimitrios Savvas ${ }^{2}$, Dimitrios Papastavrou, Georgia Ntatsi, \\ Andreas Ropokis, and C. Olympios \\ Agricultural University of Athens, Department of Crop Science, Laboratory \\ of Vegetable Production, Iera Odos 75, 11855 Athens, Greece
}

\section{Hagen Hartmann ${ }^{1}$ and Dietmar Schwarz Institute for Vegetable and Ornamental Crops, Theodor Echtermeyer Weg 1, 14979 Großbeeren, Germany}

Additional index words. He-Man, manganese, rootstock, Solanum lycopersicum, tomato nutrition, nutrient solution

\begin{abstract}
Tomato (Solanum lycopersicum $\mathrm{L}$. cv. Belladona $\mathrm{F}_{1}$ ) plants were either selfgrafted or grafted onto the rootstock 'He-Man' and grown in recirculating nutrient solution with low, standard, or high manganese $(M n)$ concentrations $(2,15$, and $100 \mu M$, respectively). The concentrations of all nutrients except $M n$ were identical in all treatments. The objectives of the experiment were to test whether grafted tomato plants have a higher or lower ability to withstand deficient or toxic levels of $\mathrm{Mn}$ in the root zone and to study the effects of grafting on nutrient uptake and translocation to the aerial organs. Both excessive and insufficient Mn concentrations in the root zone significantly reduced the number of fruit per plant, whereas mean fruit weight was unaffected by external Mn concentrations ranging from $\approx 1$ to $100 \mu M$. The excessive external Mn concentration caused the leaf $M n$ concentration to increase beyond the critically high level at the expense of leaf and root iron and zinc concentrations but without significant differences between the grafting treatments. The fruit yield of plants grafted onto ' $\mathrm{He}-$ Man' was significantly lower than that of self-grafted plants when the Mn concentration in the root zone was excessively high. This response might be associated with the lower translocation of magnesium (Mg) to the leaves of plants grafted onto 'He-Man' in comparison with the self-grafted plants, resulting in lower $\mathrm{Mg} / \mathrm{Mn}$ ratios in the leaves. Grafting onto 'He-Man' also restricted the leaf and root iron and copper concentrations but enhanced those of potassium. Overall, tomato cv. Belladona proved to be more tolerant to excess Mn than to Mn deficiency in terms of vegetative growth and fruit yield.
\end{abstract}

Over the last 50 years, vegetable production using grafted seedlings has become a common practice in many parts of the world. To the extent grafting reduces the input of agrochemicals to the crop, it can be considered an environmentally friendly component of integrated crop management systems (Rivard and Louws, 2008). The cultivated area of grafted Solanaceae and Cucurbitaceae plants has increased tremendously in recent years because the objective of grafting has been greatly expanded to include reducing infections by soilborne

\footnotetext{
Received for publication 5 June 2009. Accepted for publication 31 July 2009.

This investigation was partly supported by a project-based personnel exchange program between Greece and Germany (IKYDA 2007, contract No. 115)

Reviewing of the English by Prof. Harold C. Passam is greatly appreciated.

${ }^{1}$ Current address: Forschungs- und Studienzentrum Landwirtschaft und Umwelt Georg-AugustUniversität Göttingen, Am Vogelsang 6, 37075 Göttingen, Germany.

${ }^{2}$ To whom reprint requests should be addressed; e-maildsavvas@aua.gr.
}

pathogens (Davis et al., 2008; Tsror and Nachmias, 1995); tolerance against abiotic stresses such as salt, wet soils, and low temperature (Abdelmageed and Gruda, 2009; Ahn et al., 1999; Fernández-García et al., 2002; Venema et al., 2008); enhancing water, nutrient uptake, and nutrient use efficiency (Santa-Cruz et al., 2002), increasing plant vigor (Lee et al., 1998); extending the duration of harvest time (Lee, 1994); and improving fruit quality (Matsuzoe et al., 1996). Although grafted tomatoes seem to have greater nutrient uptake efficiency, there have been few investigations in this area (Fernández-García et al., 2002). However, an essential prerequisite for successful grafting is the selection of rootstocks that do not adversely affect plant nutrition, fruit yield, and produce quality.

As reported by Edelstein and Ben-Hur (2007), the concentrations of heavy metals and microelements, including manganese $(\mathrm{Mn})$, zinc $(\mathrm{Zn})$, copper $(\mathrm{Cu})$, and boron $(\mathrm{B})$ in grafted melon plants were substantially lower than those measured in nongrafted plants of the same cultivar. Rouphael et al. (2008) found that grafting may appreciably affect the uptake of micronutrients such as $\mathrm{Cu}$ in cucumber. The suppression of nutrient uptake by rootstocks used to graft greenhouse vegetables may adversely affect plant performance under conditions of inadequate supply. On the other hand, a restriction of micronutrient and nonnutrient heavy metal uptake may be advantageous when the availability of such elements in the soil or growth medium is excessively high attributable, for instance, to a low external $\mathrm{pH}$. Hence, it is of interest to know how grafted plants such as tomato respond to excessively high or low levels of some micronutrients in the root environment.

In view of this background, the present investigation was designed to study the effects of the rootstock on tomato growth, yield, and nutrient uptake under conditions of standard or excessively low or high $\mathrm{Mn}$ levels in the rooting medium. The question to be answered through the present investigation is whether grafted plants have a higher or lower ability to withstand deficient or toxic levels of micronutrients in the root environment. Mn was selected as the test element because deficiency or toxicity problems with this micronutrient are frequent in greenhouse crops (Shenker et al., 2004; Sonneveld et al., 1977).

\section{Materials and Methods}

The experiment was conducted in a heated glasshouse at the Agricultural University of Athens. On 20 Sept. 2007, grafted seedlings of tomato (Solanum lycopersicum L. cv. Belladona; Hazera Seeds Ltd., Haifa, Israel), raised in a mixture of peat and perlite, were transferred to 12 channels with recirculating nutrient solution (NS) at the stage of four to five true leaves. Before transplanting, the roots of the young seedlings were carefully washed in plain water to remove the aggregates of the growing medium. Half of the plants had been grafted onto the rootstock 'He-Man' (Solanum lycopersicum $\times$ Solanum habrochaites; Syngenta Seeds, Basel, Switzerland) and the other half were self-grafted. Each channel was $5.5 \mathrm{~m}$ in length, $0.2 \mathrm{~m}$ in width, and $0.08 \mathrm{~m}$ in height and accommodated eight tomato plants.

As a second treatment factor, $\mathrm{Mn}$ in the nutrient solution was adjusted to a low, a standard, and a high concentration corresponding to 2,10 , and $50 \mu \mathrm{M} \mathrm{Mn}$, respectively, during the initial $46 \mathrm{~d}$ after planting and 2, 15 and $100 \mu \mathrm{M} \mathrm{Mn}$, respectively, thereafter. The different $\mathrm{Mn}$ levels were attained by adding appropriate amounts of $\mathrm{MnSO}_{4} \cdot \mathrm{H}_{2} \mathrm{O}$ to the nutrient solution. The concentrations of all other nutrients in the solution initially introduced into the system (SNS) were identical for all NS treatments and the composition was as follows: $8.40 \mathrm{~mm}$ $\mathrm{K}^{+}, 5.75 \mathrm{mM} \mathrm{Ca}^{2+}, 2.75 \mathrm{mM} \mathrm{Mg}^{2+}, 1.00 \mathrm{~mm}$ $\mathrm{NH}_{4}^{+}, 17.00 \mathrm{~mm} \mathrm{NO}_{3}^{-}, 1.25 \mathrm{mM} \mathrm{H}_{2} \mathrm{PO}_{4}^{-}, 4.00$ $\mathrm{mM} \mathrm{SO}_{4}{ }^{2-}, 15 \mu \mathrm{M}$ iron (Fe), $5 \mu \mathrm{M} \mathrm{Zn}, 0.7 \mu \mathrm{M}$ $\mathrm{Cu}, 40 \mu \mathrm{MB}$, and $0.5 \mu \mathrm{M}$ molybdenum (Mo). To maintain these concentrations in the recirculating NS, replenishment nutrient solutions (RNS) with the following composition were 
introduced to each experimental unit during the experiment to compensate for nutrient and water uptake by the tomato plants: 6.25 $\mathrm{mm} \mathrm{K}+2.75 \mathrm{mM} \mathrm{Ca}^{++}, 1.50 \mathrm{~mm} \mathrm{Mg}^{2+}, 1.00$ $\mathrm{mM} \mathrm{NH}_{4}^{+}, 11.50 \mathrm{~mm} \mathrm{NO}_{3}^{-}, 1.00 \mathrm{~mm} \mathrm{H}_{2} \mathrm{PO}_{4}^{-}$, $1.50 \mathrm{mM} \mathrm{SO}_{4}{ }^{2-}, 15 \mu \mathrm{M} \mathrm{Fe}, 4 \mu \mathrm{M} \mathrm{Zn}, 0.6 \mu \mathrm{M}$ $\mathrm{Cu}, 20 \mu \mathrm{M} \mathrm{B}$, and $0.5 \mu \mathrm{M} \mathrm{Mo}$. To avoid nutrient imbalances in the root environment, the recirculating nutrient solutions were discharged and replaced with fresh SNS on Days 46 and 92 after treatment initiation.

The three Mn treatments were combined with the two grafting treatments in a twofactorial experimental design rendering six treatments. Each treatment was replicated four times and contained four plants. Thus, the total number of tomato plants was 96 . The nutrient solutions were automatically pumped at a rate of $0.1 \mathrm{~m}^{3} \cdot \mathrm{h}^{-1}$ to each channel and were recirculated continually day and night. The volume of recirculating nutrient solution per plant amounted to $6 \mathrm{~L}$ in all treatments. The amount of NS consumed by the plants was automatically detected by mechanical floaters and replaced with RNS from the storage tanks, thereby maintaining constant NS levels in the tanks used to supply NS to the channels. The $\mathrm{pH}$ in the recirculating NS was adjusted to 5.6 to 5.7 daily by adding appropriate amounts of $1 \mathrm{~N} \mathrm{HNO}_{3}$ stock solution.

Fruit setting was facilitated by vibration of the trusses at approximately midday twice a week. To avoid limitations in fruit setting resulting from insufficient pollen production or pollen tube growth, the inside air temperature was maintained to levels above $15^{\circ} \mathrm{C}$ during the night and $18{ }^{\circ} \mathrm{C}$ during the day. The harvesting of commercially ripe fruit started on 12 Dec. 2007 and was repeated twice a week until the end of the experiment on 4 Feb. 2008. At each harvest, the total number and weight of harvested fruit were recorded separately in each experimental unit. At crop termination, two plants were harvested from each experimental unit and divided into stems and leaves. Subsequently, the leaf and stem samples were chopped and a representative sample of $200 \mathrm{~g}$ from each was oven-dried at $72{ }^{\circ} \mathrm{C}$ to constant weight. After drying, the weight of all samples was measured and used to determine the total stem and leaf dry mass per plant.

At regular time intervals, samples of recirculating NS were selected from all experimental units and used to determine the actual Mn concentration. On two dates during the growing period ( 50 and $92 \mathrm{~d}$ after planting and $\mathrm{Mn}$ treatment initiation), samples of the youngest fully expanded leaves were collected from all experimental units and dried at $72{ }^{\circ} \mathrm{C}$ to constant weight. Furthermore, root samples were also collected from all experimental units at crop termination (137 $\mathrm{d}$ after planting) and dried at the same temperature $\left(72^{\circ} \mathrm{C}\right)$. Subsequently, the leaf and root samples were powdered using a ball mill, passed through a 40-mesh sieve, subjected to dry ashing in a muffle furnace at $550{ }^{\circ} \mathrm{C}$ for $5 \mathrm{~h}$, and used to extract potassium $(\mathrm{K})$, calcium $(\mathrm{Ca})$, magnesium $(\mathrm{Mg}), \mathrm{Fe}, \mathrm{Mn}$,
$\mathrm{Zn}$, and $\mathrm{Cu}$ by means of $1 \mathrm{~N} \mathrm{HCl}$. The concentrations of $\mathrm{Mn}$ in the nutrient solutions and $\mathrm{Ca}, \mathrm{Mg}, \mathrm{Fe}, \mathrm{Mn}, \mathrm{Zn}$, and $\mathrm{Cu}$ in the aqueous extracts were determined by atomic absorption spectrophotometry (Perkin Elmer $1100 \mathrm{~B}$, Waltham, MA) and potassium by flame photometry (Sherwood Model 410, Cambridge, UK).

The data were subjected to two-factorial analysis of variance using the PlotIT3.2 ${ }^{\circledR}$ work package (Scientific Programming Enterprises, Haslett, MI). When the Mn supply level was significant, the means among the three tested Mn levels were separated using Duncan's multiple range test $(P<0.05)$. The same test was used to separate the six means from all experimental treatments when the interaction for a particular measured characteristic was significant.

\section{Results}

In all Mn treatments, the concentration of $\mathrm{Mn}$ in the recirculating nutrient solution tended to decrease to lower levels than those in the corresponding solutions introduced to the closed-loop system to compensate for plant uptake (Fig. 1). During the first days after the introduction of fresh nutrient solution in the closed system, a sharp decrease in the Mn concentration was observed in the recirculating solution, which was subsequently followed either by a stabilization of the $\mathrm{Mn}$ level or by a much slower rate of decrease.

The high Mn supply treatments exhibited symptoms of toxicity toward the end of the experiment, whereas the low Mn supply did not cause visible deficiency symptoms in the tomato plants, irrespective of whether the plants were self-grafted or grafted onto ' $\mathrm{He}$ Man' rootstocks. Mn toxicity appeared first as severe interveinal chlorosis resembling $\mathrm{Fe}$ deficiency in the upper leaves, which was followed by the occurrence of extensive dark spots on the leaf veins. Both the Mn level and the rootstock affected the uptake and translocation of nutrients to the tomato shoot as indicated by the leaf nutrient concentrations $92 \mathrm{~d}$ after planting (Table 1). Similar results were obtained with the leaf samples collected $50 \mathrm{~d}$ after planting (data not shown). Of the two experimental factors, the level of $\mathrm{Mn}$ significantly affected the leaf $\mathrm{Mn}, \mathrm{Fe}$, and $\mathrm{Zn}$ concentrations, whereas the rootstock had a significant impact on the leaf $\mathrm{Mg}, \mathrm{K}, \mathrm{Fe}$, and $\mathrm{Cu}$ concentrations. Specifically, the increase in the Mn supply level raised the Mn and restricted the $\mathrm{Fe}$ and $\mathrm{Zn}$ concentrations in the leaves of tomato regardless of the mode of grafting. The leaves of plants grafted onto 'He-Man' exhibited lower $\mathrm{Mg}, \mathrm{Cu}$, and $\mathrm{Fe}$ but higher $\mathrm{K}$ levels in comparison with those from self-grafted plants. As indicated by the interaction between grafting and $\mathrm{Mn}$ level, the difference in the leaf $\mathrm{Fe}$ between self-grafted plants and those grafted onto 'He-Man' tended to be larger at low rather than at standard or excessively high Mn levels in the root zone.

As shown in Table 2, the Mn supply level had a strong impact not only on micronutrient $(\mathrm{Mn}, \mathrm{Fe}, \mathrm{Zn}, \mathrm{Cu})$, but also on the measured
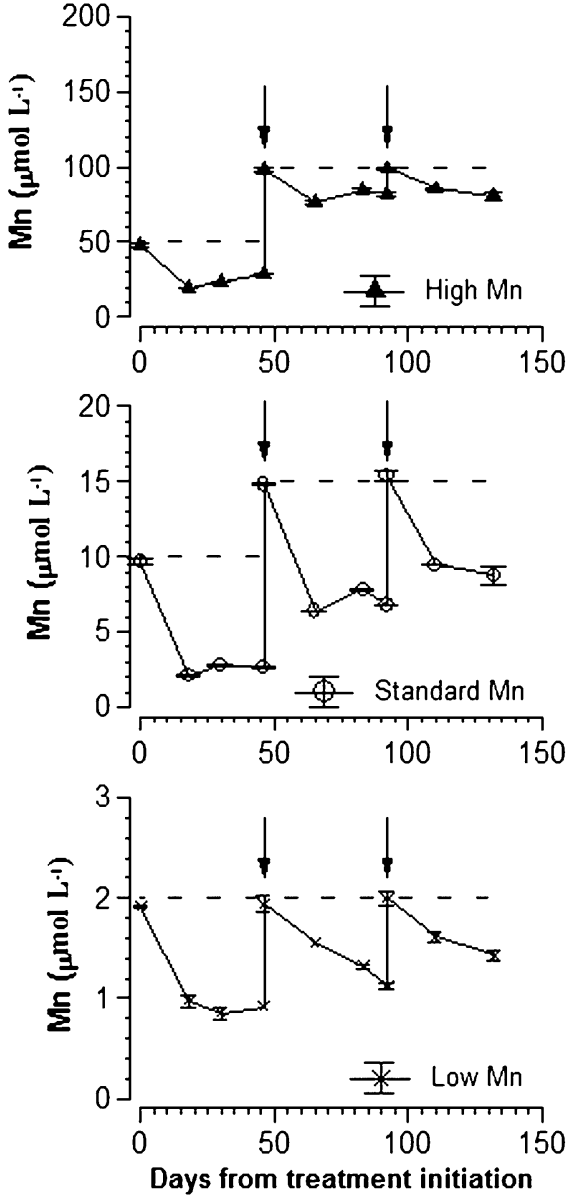

Fig. 1. Evolution of the manganese (Mn) concentration in the recirculating nutrient solution as influenced by the Mn level (high, standard, and low, indicated by the broken lines) in the nutrient solution introduced to the system to compensate for tomato plant uptake. Vertical arrows indicate days of nutrient solution renewal.

macronutrient $(\mathrm{Ca}, \mathrm{Mg}, \mathrm{K})$ concentrations in the roots of tomato regardless of the root genotype ('Belladona' or 'He-Man'). Specifically, the increase in Mn supply level markedly restricted the $\mathrm{Ca}, \mathrm{Mg}, \mathrm{Fe}, \mathrm{Mn}$, and $\mathrm{Cu}$ concentrations and appreciably enhanced that of Mn but only slightly that of $\mathrm{K}$ in the roots of tomato. In the case of $\mathrm{Mg}, \mathrm{K}$, and $\mathrm{Fe}$, only the excessively high Mn supply level imposed a significant difference in the root concentrations in comparison with those measured in the standard and low Mn supply levels. However, the root $\mathrm{Ca}, \mathrm{Zn}$, and $\mathrm{Cu}$ concentrations tended to decline constantly, whereas $\mathrm{Mn}$ rose with each increment in $\mathrm{Mn}$ supply. The grafting of tomato onto ' $\mathrm{He}$ Man' increased the root $\mathrm{Mg}$ and $\mathrm{K}$ concentrations; reduced $\mathrm{Mn}, \mathrm{Fe}$, and $\mathrm{Cu}$; but had no effect on the root $\mathrm{Ca}$ level. The standard and high Mn supply levels significantly decreased the root Mn concentration of plants grafted onto 'He-Man', whereas the root Fe concentration differed significantly between the two root genotypes only at the standard external Mn concentration.

Grafting 'Belladona' on 'He-Man' or on its own roots had no impact on the aboveground vegetative growth of tomato as indicated by 
Table 1. Leaf nutrient concentrations in tomato ('Belladona' $F_{1}$ ) grown in recirculating nutrient solution as influenced by grafting (either self-grafted or grafted onto the rootstock 'He-Man') and manganese (Mn) supply level (high, standard, and low) in the nutrient solution introduced to the system to compensate for plant uptake. ${ }^{z}$

\begin{tabular}{|c|c|c|c|c|c|c|c|c|}
\hline \multirow[b]{2}{*}{ Mn level } & \multirow[b]{2}{*}{ Rootstock } & Calcium & Magnesium & Potassium & $\mathrm{Mn}$ & Iron & Zinc & Copper \\
\hline & & \multicolumn{3}{|c|}{$\left(\mathrm{mg} \cdot \mathrm{g}^{-1}\right.$ dry wt) } & \multicolumn{4}{|c|}{$\left(\mathrm{mg} \cdot \mathrm{kg}^{-1}\right.$ dry wt) } \\
\hline \multirow[t]{2}{*}{ High } & Belladona & 14.0 & 5.20 & 79.8 & 280 & $77 \mathrm{~d}$ & 21.5 & 16.0 \\
\hline & He-Man & 17.2 & 3.14 & 90.0 & 294 & $69 \mathrm{~d}$ & 21.8 & 11.5 \\
\hline \multirow[t]{2}{*}{ Standard } & Belladona & 15.0 & 5.04 & 81.8 & 157 & $128 \mathrm{c}$ & 24.3 & 16.5 \\
\hline & He-Man & 12.2 & 2.92 & 91.3 & 143 & $116 \mathrm{c}$ & 24.0 & 13.5 \\
\hline \multirow[t]{2}{*}{ Low } & Belladona & 13.9 & 5.22 & 87.5 & 36 & $288 \mathrm{a}$ & 35.5 & 20.8 \\
\hline & He-Man & 18.0 & 3.28 & 94.8 & 33 & $226 \mathrm{~b}$ & 39.5 & 12.5 \\
\hline \multicolumn{9}{|l|}{ Main effects } \\
\hline \multirow[t]{3}{*}{ Mn level } & High & 15.6 & 4.17 & 84.9 & $287 \mathrm{a}$ & $73 \mathrm{a}$ & $21.6 \mathrm{~b}$ & 13.8 \\
\hline & Standard & 13.6 & 3.98 & 86.5 & $150 \mathrm{~b}$ & $122 \mathrm{~b}$ & $24.1 \mathrm{~b}$ & 15.0 \\
\hline & Low & 15.9 & 4.25 & 91.1 & $35 \mathrm{c}$ & $257 \mathrm{c}$ & $37.5 \mathrm{a}$ & 16.6 \\
\hline \multirow[t]{2}{*}{ Rootstock } & Belladona & 14.3 & 5.15 & 83.0 & 158 & 164 & 27.1 & 17.8 \\
\hline & He-Man & 15.8 & 3.11 & 92.0 & 157 & 137 & 28.4 & 12.5 \\
\hline \multicolumn{9}{|c|}{ Statistical significance } \\
\hline \multicolumn{2}{|c|}{ Mn level } & NS & NS & NS & $* * *$ & $* * *$ & $* * *$ & NS \\
\hline \multicolumn{2}{|c|}{ Rootstock } & NS & $* * *$ & $* *$ & NS & $* *$ & NS & $* * *$ \\
\hline \multicolumn{2}{|c|}{ Mn level $\times$ rootstock } & NS & NS & NS & NS & $*$ & NS & NS \\
\hline
\end{tabular}

${ }^{\mathrm{z} L e a v e s}$ were sampled $92 \mathrm{~d}$ after planting.

$\mathrm{NS}, * * *$, and $* * *$ indicate nonsignificant or significant at $P \leq 0.05,0.01$, and 0.001 , respectively. When more than two means are compared, different letters in a column indicate significant differences at $P \leq$ 0.05 according to the Duncan's multirange test.

Table 2. Root nutrient concentrations in 'Belladona' or 'He-Man' grafted with scions of tomato ('Belladona' $\mathrm{F}_{1}$ ) grown in a recirculating nutrient solution as influenced by the manganese $(\mathrm{Mn})$ level in the nutrient solution introduced to the system to compensate for plant uptake. ${ }^{\mathrm{z}}$

\begin{tabular}{|c|c|c|c|c|c|c|c|c|}
\hline \multirow[b]{2}{*}{ Mn level } & \multirow[b]{2}{*}{ Rootstock } & Calcium & Magnesium & Potassium & Mn & Iron & Zinc & Copper \\
\hline & & \multicolumn{3}{|c|}{$\left(\mathrm{mg} \cdot \mathrm{g}^{-1}\right.$ dry wt) } & \multicolumn{4}{|c|}{$\left(\mathrm{mg} \cdot \mathrm{kg}^{-1}\right.$ dry wt) } \\
\hline \multirow[t]{2}{*}{ High } & Belladona & 6.9 & 2.09 & 73.5 & $198 \mathrm{a}$ & $567 \mathrm{c}$ & 174 & 65 \\
\hline & He-Man & 7.3 & 2.46 & 82.3 & $162 \mathrm{~b}$ & $574 \mathrm{c}$ & 145 & 57 \\
\hline \multirow[t]{2}{*}{ Standard } & Belladona & 10.9 & 3.79 & 61.3 & $145 \mathrm{~b}$ & $1252 \mathrm{a}$ & 328 & 124 \\
\hline & He-Man & 10.8 & 4.66 & 74.8 & $90 \mathrm{c}$ & $877 \mathrm{~b}$ & 331 & 91 \\
\hline \multirow[t]{2}{*}{ Low } & Belladona & 15.4 & 4.37 & 57.4 & $36 \mathrm{~d}$ & $1235 \mathrm{a}$ & 377 & 158 \\
\hline & He-Man & 16.7 & 4.60 & 62.8 & $30 \mathrm{~d}$ & $1083 \mathrm{a}$ & 394 & 114 \\
\hline \multicolumn{9}{|l|}{ Main effects } \\
\hline \multirow[t]{3}{*}{ Mn level } & High & $7.1 \mathrm{c}$ & $2.27 \mathrm{~b}$ & $77.9 \mathrm{a}$ & $180 \mathrm{a}$ & $570 \mathrm{~b}$ & $159 \mathrm{c}$ & $61 \mathrm{c}$ \\
\hline & Standard & $10.9 \mathrm{~b}$ & $4.22 \mathrm{a}$ & $66.1 \mathrm{~b}$ & $117 \mathrm{~b}$ & $1065 \mathrm{a}$ & $330 \mathrm{~b}$ & $107 \mathrm{~b}$ \\
\hline & Low & $16.0 \mathrm{a}$ & $4.48 \mathrm{a}$ & $62.0 \mathrm{~b}$ & $33 \mathrm{c}$ & $1158 \mathrm{a}$ & $385 \mathrm{a}$ & $136 \mathrm{a}$ \\
\hline \multirow[t]{2}{*}{ Rootstock } & Belladona & 11.1 & 3.42 & 64.0 & 126 & 1018 & 293 & 116 \\
\hline & He-Man & 11.6 & 3.91 & 73.3 & 94 & 844 & 290 & 87 \\
\hline \multicolumn{9}{|c|}{ Statistical significance } \\
\hline \multicolumn{2}{|c|}{ Mn level } & $* * *$ & $* * *$ & $* *$ & $* * *$ & $* * *$ & $* * *$ & $* * *$ \\
\hline \multicolumn{2}{|c|}{ Rootstock } & NS & $*$ & $*$ & ** & $* *$ & NS & ** \\
\hline \multicolumn{2}{|c|}{ Mn level $\times$ rootstock } & NS & NS & NS & * & $*$ & NS & NS \\
\hline
\end{tabular}

${ }^{\mathrm{z} R o o t s}$ were sampled $137 \mathrm{~d}$ after planting.

NS, $* * *$, and $* * *$ indicate nonsignificant or significant at $P \leq 0.05,0.01$, and 0.001 , respectively. When more than two means are compared, different letters in a column indicate significant differences at $P \leq$ 0.05 according to the Duncan's multirange test.

the stem and leaf dry weight (Fig. 2). The Mn supply level did not affect the stem dry weight, but the leaf dry weight was significantly restricted when the replenishment nutrient solution contained only $2 \mathrm{~mm} \mathrm{Mn}$. The excessively high Mn supply level had no significant impact on stem and root biomass.

Unlike the aboveground vegetative growth, the fruit yield of tomato was significantly influenced by both the level of $\mathrm{Mn}$ supply and the rootstock (Table 3). Overall, the supply of $\mathrm{Mn}$ at levels far below or far above the standard recommendations for tomato significantly reduced the total fruit weight per plant mainly as a result of a decrease in the number of fruits per plant, whereas the mean fruit weight was unaffected significantly by the Mn level. The

\section{Discussion}

The lower Mn levels in the recirculating NS in comparison with the solutions supplied to the crop to compensate for plant uptake (RNS) cannot be ascribed to active absorption, because a tendency to decrease was also observed in the excessively high Mn treatments. Bromfield (1978) and Sonneveld and Voogt (1980) also observed a tendency for Mn to be depleted in the root zone of soillessgrown crops and ascribed this phenomenon to immobilization of soluble Mn by oxidizing bacteria, which are common in nutrient solutions. It seems, therefore, that in our experiment, part of the Mn supplied to the plants through the NS was immobilized by microorganisms. The microbial oxidation of $\mathrm{Mn}$ in NS is beneficial when Mn is supplied at excessively high rates but potentially harmful if $\mathrm{Mn}$ is supplied at rates close to the standard requirements for plant uptake.

As expected, increasing the Mn level in the root zone resulted in similar increases in the $\mathrm{Mn}$ concentration in both the roots and leaves of tomato and these results are in agreement with previous reports (Le Bot et al., 1990). However, our results clearly show that the changes in the external $\mathrm{Mn}$ concentration in tomato also affect the uptake of $\mathrm{Fe}$ and $\mathrm{Zn}$. Our results regarding the impact of $\mathrm{Mn}$ on Fe uptake by tomato are in agreement with those reported by AlvarezTinaut et al. (1980), who found that deficient or normal Mn levels antagonized Fe absorption, but the reverse was true when Mn reached toxic values. The suppressive effect of $\mathrm{Mn}$ on $\mathrm{Fe}$ and $\mathrm{Zn}$ uptake is ascribed to mutual competition for uptake mediated by common metal transporters located in the plasma membrane, as suggested by Korshunova et al. (1999) and Marschner (1995). However, the external Mn concentration had no impact on the uptake of $\mathrm{Cu}$. As reported by Harrison et al. (1983), $\mathrm{Cu}$ and $\mathrm{Mn}$ compete for a common site for uptake, but $\mathrm{Cu}$ has a higher affinity than Mn. Landi and Fagioli (1983) also found no effect of $\mathrm{Mn}$ on $\mathrm{Cu}$ uptake by excised maize roots. Mengel (1984) states that $\mathrm{Cu}$ is much more competitive with respect to plant uptake than $\mathrm{Mn}, \mathrm{Fe}$, and $\mathrm{Zn}$, and therefore concentration changes of the latter ions in the external medium may have little or no impact on $\mathrm{Cu}$ absorption. Our results demonstrated this attribute of $\mathrm{Cu}$ also for tomato, at least with respect to the interference of $\mathrm{Cu}$ uptake by $\mathrm{Mn}$. Nevertheless, $\mathrm{Mn}$ had a highly significant suppressive effect on the root $\mathrm{Cu}$ concentration, which indicates that the efficiency of $\mathrm{Cu}$ to withstand $\mathrm{Mn}$ antagonism is restricted only to $\mathrm{Cu}$ translocation to the shoot.

In agreement with previous reports of Edelstein and Ben-Hur (2007) and Rouphael et al. (2008) for grafted melon and cucumber, respectively, the rootstock imposed noticeable changes on the efficiency of grafted tomato plants to take up $\mathrm{Mg}, \mathrm{K}, \mathrm{Fe}$, and $\mathrm{Cu}$. Differences in $\mathrm{Fe}$ and $\mathrm{Cu}$ uptake efficiency between cultivars of the same species may be attributed to dissimilarities in the excretion of 

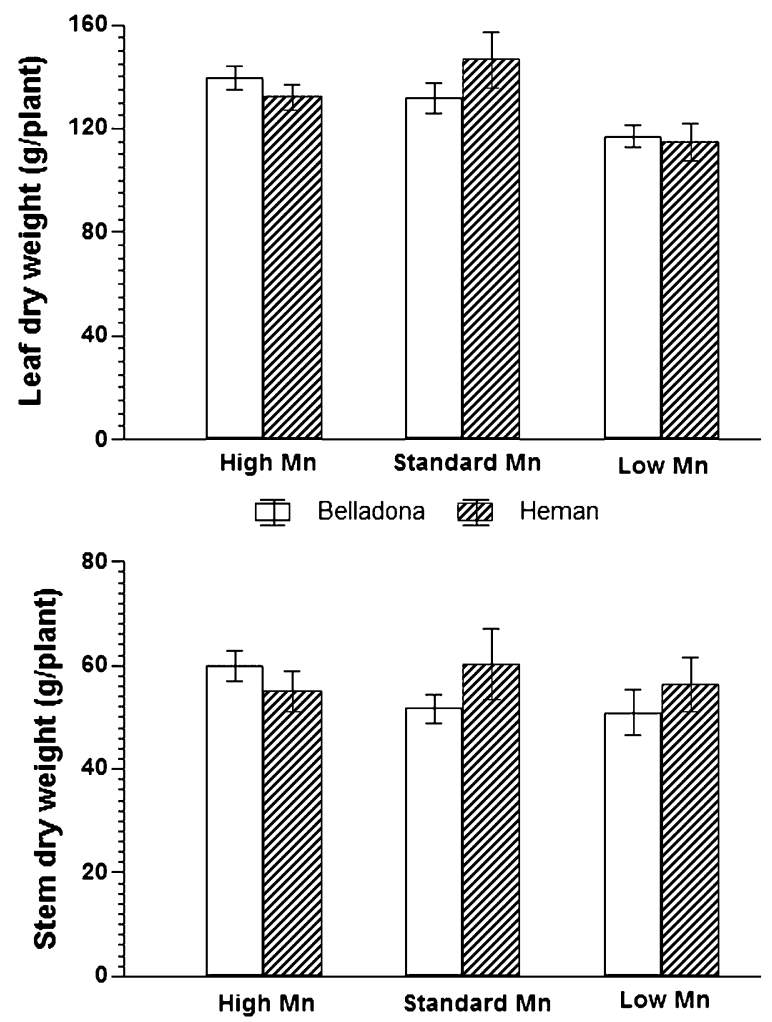

Fig. 2. Stem and leaf dry weight of tomato ('Belladona' $F_{1}$ ) plants grown in recirculating nutrient solution as influenced by grafting (either self-grafted or grafted onto the rootstock 'He-Man') and manganese (Mn) supply level (high, standard, and low) in the nutrient solution introduced to the system to compensate for plant uptake. Plants were sampled at crop termination (137 d after planting).

Table 3. Fruit yield and yield components of tomato ('Belladona' $F_{1}$ ) grown in recirculating nutrient solution as influenced by grafting (either self-grafted or grafted onto the rootstock 'He-Man') and manganese (Mn) supply level (high, standard, and low) in the nutrient solution introduced to the system to compensate for plant uptake.

\begin{tabular}{|c|c|c|c|c|}
\hline Mn level & Rootstock & $\begin{array}{l}\text { Total fruit wt } \\
\text { (kg/plant) }\end{array}$ & $\begin{array}{l}\text { Total fruit number } \\
\text { (fruits/plant) }\end{array}$ & $\begin{array}{l}\text { Mean fruit wt } \\
\text { (g/fruit) }\end{array}$ \\
\hline \multirow[t]{2}{*}{ High } & Belladona & $2.595 \mathrm{a}$ & $14.250 \mathrm{a}$ & 182 \\
\hline & He-Man & $2.162 \mathrm{bc}$ & $11.938 \mathrm{~b}$ & 189 \\
\hline \multirow[t]{2}{*}{ Standard } & Belladona & $2.607 \mathrm{a}$ & $13.875 \mathrm{a}$ & 180 \\
\hline & He-Man & $2.649 \mathrm{a}$ & $14.375 \mathrm{a}$ & 181 \\
\hline \multirow[t]{2}{*}{ Low } & Belladona & $2.330 \mathrm{~b}$ & $12.938 \mathrm{ab}$ & 184 \\
\hline & He-Man & $1.960 \mathrm{c}$ & $11.563 \mathrm{~b}$ & 171 \\
\hline \multicolumn{5}{|l|}{ Main effects } \\
\hline \multirow[t]{3}{*}{ Mn level } & High & $2.378 \mathrm{~b}$ & $13.094 \mathrm{ab}$ & 185 \\
\hline & Standard & $2.628 \mathrm{a}$ & $14.125 \mathrm{a}$ & 181 \\
\hline & Low & $2.145 \mathrm{c}$ & $12.250 \mathrm{~b}$ & 178 \\
\hline \multirow[t]{2}{*}{ Rootstock } & Belladona & 2.511 & 13.688 & 182 \\
\hline & He-Man & 2.257 & 12.625 & 180 \\
\hline \multicolumn{5}{|c|}{ Statistical significance } \\
\hline \multicolumn{2}{|c|}{ Mn level } & $* *$ & $* *$ & NS \\
\hline \multicolumn{2}{|c|}{ Rootstock } & $*$ & $*$ & NS \\
\hline \multicolumn{2}{|c|}{ Mn level $\times$ rootstock } & $*$ & * & NS \\
\hline
\end{tabular}

NS, *,**, and $* * *$ indicate nonsignificant or significant at $P \leq 0.05,0.01$, and 0.001 , respectively. When more than two means are compared, different letters in a column indicate significant differences at $P \leq$ 0.05 according to the Duncan's multirange test.

phytosiderophores and other acidifying compounds, which influence the solubilization of these metals at the rhizosphere level. Thus, according to Mench and Fargues (1994), the uptake of cadmium, $\mathrm{Cu}$, lead, Mn, nickel, and $\mathrm{Zn}$ by oat tended to be greater for a $\mathrm{Fe}$ efficient than for a Fe-inefficient cultivar and this was attributed to increased solubilization of these metals by phytosiderophores. On the other hand, grafting of melon seems to re- grafted plants. Nevertheless, the concentrations of $\mathrm{Fe}$ and $\mathrm{Cu}$ in the leaves of plants grafted onto 'He-Man' were far above the lowest critical levels referred to by Marschner (1995) and Reuter and Robinson (1986) irrespective of Mn supply. Furthermore, at high external $\mathrm{Mn}$ concentrations, the tissue $\mathrm{Fe}$ concentrations in plants grafted on ' $\mathrm{He}$ Man' were similar to those in self-grafted plants and this interaction was significant. These results suggest that tomato plants grafted on 'He-Man' may be more tolerant to excessively high external $\mathrm{Fe}$ and $\mathrm{Cu}$ concentrations but not more susceptible to $\mathrm{Fe}$ or $\mathrm{Cu}$ deficiency.

Unlike the concentrations of $\mathrm{Fe}$ and $\mathrm{Cu}$ in the leaves of plants grafted on 'He-Man', the $\mathrm{Mg}$ concentration approached the lowest critical level for tomato $\left(3 \mathrm{mg} \cdot \mathrm{g}^{-1}\right.$ dry weight according to Mills and Jones, 1996). These data indicate that, to avoid $\mathrm{Mg}$ deficiency, the level of $\mathrm{Mg}$ as well as the $\mathrm{Mg}: \mathrm{K}$ and $\mathrm{Mg}: \mathrm{Ca}$ ratios in nutrient solutions supplied to tomato plants grafted on 'He-Man' should be higher than the current recommendations for nongrafted plants, as summarized by Savvas et al. (2008). In contrast to $\mathrm{Fe}$ and $\mathrm{Cu}$, the $\mathrm{Mg}$ concentration was lower in the leaves but higher in the roots of plants grafted on 'HeMan' than in self-grafted plants. It seems that the suppression of the leaf $\mathrm{Mg}$ levels in plants grafted on 'He-Man' is partly the result of a stronger retention of $\mathrm{Mg}$ in the root tissues.

Previous investigations have shown that the growth and yield of tomato may be restricted by both $\mathrm{Mn}$ deficiency and $\mathrm{Mn}$ toxicity (Shenker et al., 2004). In our study, the tomato plants were more severely affected by low ( 1 to $2 \mu \mathrm{M}$ ) than by high ( 80 to $100 \mu \mathrm{M}$ ) external Mn levels in terms of both vegetative plant growth and fruit yield. Especially the self-grafted 'Belladona' plants exhibited a higher than expected tolerance to excessive Mn levels in the recirculating NS in terms of fruit production, which did not differ significantly from that obtained with the standard Mn supply. These results indicate that this variety of tomato ('Belladona') is more susceptible to deficiency than to toxicity of $\mathrm{Mn}$, and even a latent Mn deficiency without visible symptoms may adversely affect fruit productivity. Our results, which indicate a relatively low sensitivity of tomato to excessively high Mn levels, are in agreement with Foy (1973), who classified tomato as a relatively $\mathrm{Mn}$-tolerant plant species.

Shenker et al. (2004) found that a leaf Mn concentration of $207.4 \mathrm{mg} \cdot \mathrm{kg}^{-1}$ was associated with toxicity symptoms in tomato. According to Mills and Jones (1996), a Mn concentration of $250 \mathrm{mg} \cdot \mathrm{kg}^{-1}$ in the leaf petioles is the maximum safe level for tomato. In the present experiment, the tomato plants exposed to high external Mn concentrations exhibited higher leaf Mn levels than the critical limits referred to here regardless of the grafting treatment. Despite this, only the fruit yield of plants grafted onto 'HeMan' was negatively influenced by the high Mn supply. As reported by Horst (1988) and Le Bot et al. (1990), the critical level for 
the appearance of Mn toxicity may be influenced by various other factors such as the magnesium to manganese ratio. Because the leaf $\mathrm{Mg}$ concentration was markedly lower in plants grafted on 'He-Man' than in the selfgrafted plants, whereas the Mn concentrations were similar (Table 1 ), the $\mathrm{Mg} / \mathrm{Mn}$ ratio was lower in the former and this was presumably the reason for their higher susceptibility to excessively high Mn levels.

Both the excessively high and low Mn levels in the root environment of tomato reduced the yield by restricting the number of fruits per plant but had no influence on the mean fruit weight. The suppression of fruit yield under conditions of Mn deficiency may be partly ascribed to a restriction of leaf area as indicated by the significantly lower dry leaf weight per plant in comparison with plants grown with a standard or high Mn supply (Fig. 2). However, the yield was more severely affected by the low Mn supply than the leaf mass, whereas at the high Mn supply level, the restriction of yield in plants grafted on 'HeMan' was not accompanied by any reduction in vegetative growth. Hence, it is reasonable to conclude that fruit set was affected by both too low and too high Mn supply levels.

In conclusion, grafting tomato 'Belladona' on to the rootstock 'He-Man' decreases the tolerance of the scion to both low and high Mn concentrations in the root zone. This response seems to be partly associated with the appreciably lower ability of plants grafted onto 'He-Man' to transport Mg to the leaves, which results in lower foliar $\mathrm{Mg} / \mathrm{Mn}$ ratios in comparison with self-grafted plants. On the other hand, plants grafted onto 'He-Man' may be more tolerant to excessively high external $\mathrm{Cu}$ concentrations as a result of a more efficient control of the $\mathrm{Cu}$ transport to the leaves in comparison with plants grafted onto their own roots. Furthermore, grafting onto 'He-Man' may improve the efficiency of $\mathrm{K}$ uptake. Overall, the selfgrafted tomato cultivar Belladona is more tolerant to excessively high than to inadequate Mn supply levels in terms of vegetative growth and fruit yield. Both too high and too low Mn concentrations in the root zone affect mainly the number of fruit per plant, whereas the mean fruit weight is unaffected when the external Mn concentration ranges from $\approx 1$ to $100 \mu \mathrm{M}$.

\section{Literature Cited}

Abdelmageed, A.H.A. and N. Gruda. 2009. Influence of grafting on growth, development and some physiological parameters of tomatoes under controlled heat stress conditions. Europ. J. Hort. Sci. 74:16-20.

Ahn, S.J., Y.J. Im, G.C. Chung, B.H. Cho, and S.R. Suh. 1999. Physiological responses of graftedcucumber leaves and rootstock roots affected by low root temperature. Sci. Hort. 81:397408.

Alvarez-Tinaut, M.C., A. Leal, and L.R. Martínez. 1980. Iron-manganese interaction and its relation to boron levels in tomato plants. Plant Soil 55:377-388.

Bromfield, S.M. 1978. The effect of manganeseoxidizing bacteria and $\mathrm{pH}$ on the availability of manganous ions and manganese oxides to oats in nutrient solutions. Plant Soil 49:23-29.

Davis, A.R., P. Perkins-Veazie, Y. Sakata, S. Loipez-Galarza, J.V. Maroto, S.-G. Lee, Y.-C. Huh, Z. Sun, A. Miguel, S.R. King, R. Cohen, and J.-M. Lee. 2008. Cucurbit grafting. Crit. Rev. Plant Sci. 27:50-74.

Edelstein, M. and M. Ben-Hur. 2007. Preventing contamination of supply chains by using grafted plants under irrigation with marginal water. Proc. 2nd IASTED Intern. Confer. Water Res. Manage., 20-22 Aug. 2007, Honolulu, HI. p. $150-154$.

Edelstein, M., M. Ben-Hur, and Z. Plaut. 2007. Grafted melons irrigated with fresh or effluent water tolerate excess boron. J. Amer. Soc. Hort. Sci. 132:484-491.

Fernaìndez-Garciìa, N., V. Martiìnez, A. Cerdaì, and M. Carvajal. 2002. Water and nutrient uptake of grafted tomato plants grown under saline conditions. J. Plant Physiol. 159:899905.

Foy, C.D. 1973. Manganese and plants. Monogr. Manganese, Nation. Acad. Sci., Nation. Res. Counc., Washington, DC. p. 51-76.

Harrison, S.J., N.W. Lepp, and D.A. Phipps. 1983. Copper uptake by excised roots. 3. Effect of manganese on copper uptake. Z. Pflanzenphysiol. 109:285-289.

Horst, W.J. 1988. The physiology of manganese toxicity, p. 175-188. In: Graham, R.D., R.J. Hannam, and N.C. Uren (eds.). Manganese in soils and plants. Kluwer Academic Publishers, Dordrecht, The Netherlands.

Korshunova, Y.O., D. Eide, W.G. Clark, M.L. Guerinot, and H.B. Pakrasi. 1999. The IRT1 protein from Arabidopsis thaliana is a metal transporter with a broad substrate range. Plant Mol. Biol. 40:37-44.

Landi, S. and F. Fagioli. 1983. Efficiency of manganese and copper nutrition of canola. Can. J. Soil Sci. 69:119-125.

Le Bot, J., M.J. Goss, G.P.R. Carvalho, M.L. van Beusichem, and E.A. Kirby. 1990. The significance of magnesium to manganese ratio in plant tissues for growth and alleviation of manganese toxicity in tomato (Lycopersicon esculentum) and wheat (Triticum sativum) plants. Plant Soil 124:205-210.
Lee, J.M. 1994. Cultivation of grafted vegetables 1. Current status, grafting methods, and benefits. HortScience 29:235-239.

Lee, J.M., H.J. Bang, and H.S. Ham. 1998. Grafting of vegetables. J. Jpn. Soc. Hort. Sci. 67:10981114.

Marschner, H. 1995. Mineral nutrition of higher plants. 2nd Ed. Academic Press, London, UK.

Matsuzoe, N., H. Aida, K. Hanada, M. Ali, H. Okubo, and K. Fujieda. 1996. Fruit quality of tomato plants grafted on Solanum rootstocks. J. Jpn. Soc. Hort. Sci. 65:73-80.

Mench, M.J. and S. Fargues. 1994. Metal uptake by iron-efficient and inefficient oats. Plant Soil 165:227-233.

Mengel, K. 1984. Ernährung und Stoffwechsel der Pflanze. 6th Ed. Gustav Fischer Verlag, Stuttgart, Germany.

Mills, H.A. and J. Jones, Jr. 1996. Plant analysis handbook II. MicroMacro Publishing, Inc., Athens, GA.

Reuter, D.J. and J.B. Robinson. 1986. Plant analysis, an interpretation manual. Inkata Press, Melbourne, Australia.

Rivard, C.L. and F.J. Louws. 2008. Grafting to manage soilborne diseases in heirloom tomato production. HortScience 43:2104-2111.

Rouphael, Y., M. Cardarelli, E. Rea, and G. Colla. 2008. Grafting of cucumber as a means to minimize copper toxicity. Environ. Exp. Bot. 63:49-58.

Santa-Cruz, A., M.M. Martinez-Rodriguez, F. Perez-Alfocea, R. Romero-Aranda, and M.C. Bolarin. 2002. The rootstock effect on the tomato salinity response depends on the shoot genotype. Plant Sci. 162:825-831.

Savvas, D., G. Ntatsi, and H.C. Passam. 2008. Plant nutrition and physiological disorders in greenhouse grown tomato, pepper and eggplant. Europ. J. Plant Sci. Biotechn. 2:45-61.

Shenker, M., O.E. Plessner, and E. Tel-Or. 2004. Manganese nutrition effects on tomato growth, chlorophyll concentration, and superoxide dismutase activity. J. Plant Physiol. 161:197202.

Sonneveld, C. and S.J. Voogt. 1980. The application of manganese in nutrient solutions for tomatoes grown in a recirculating system. Acta Hort. 98:171-178.

Sonneveld, C., S.J. Voogt, and P.A. van Dijk. 1977. Methods for the determination of toxic levels of manganese in glasshouse soils. Plant Soil 46:487-497.

Tsror, L. and A. Nachmias. 1995. Significance of the root system in Verticillium wilt tolerance in potato and resistance in tomato. Isr. J. Plant Sci. 43:315-323.

Venema, J.H., B.E. Dijk, J.M. Bax, P.R. van Hasselt, and J.T.M. Elzenga. 2008. Grafting tomato (Solanum lycopersicum) onto the rootstock of a high-altitude accession of Solanum habrochaites improves suboptimal-temperature tolerance. Environ. Exp. Bot. 63:359-367. 